\title{
Mid-infrared spectrometry prediction of the cheese-making properties of raw Montbéliarde milks from herds and cheese dairy vats used for the production of Protected Designation of Origin and Protected Geographical Indication cheeses in Franche-Comté
}

\author{
M. El Jabri, ${ }^{1} \odot$ P. Trossat,${ }^{2}$ V. Wolf, ${ }^{3}$ E. Beuvier, ${ }^{4} \odot$ O. Rolet-Répécaud, ${ }^{4}$ S. Gavoye ${ }^{2 *}$ Y. Gaüzère,${ }^{5}$ \\ O. Belysheva, ${ }^{5}$ N. Gaudillière, ${ }^{3}$ E. Notz, ${ }^{6}$ P. Grosperrin, ${ }^{3}$ C. Laithier, ${ }^{1}$ and A. Delacroix-Buchet ${ }^{7} \dagger{ }^{\circ}$ \\ ${ }^{1}$ Institut de l'Elevage, F-75012 Paris, France \\ ${ }^{2}$ ACTALIA, F-39800 Poligny, France \\ ${ }^{3}$ Conseil Elevage 25-90, F-25640 Roulans, France \\ ${ }^{4}$ INRAE, URTAL, F-39800, Poligny, France \\ ${ }^{5}$ Ecole Nationale d'Industrie Laitière et des Biotechnologies, F-39800 Poligny, France \\ ${ }^{6}$ Centre Technique des Fromages Comtois, F-39800, Poligny, France \\ ${ }^{7}$ Université Paris Saclay, INRAE, AgroParisTech, GABI, F-78350 Jouy-en-Josas, France
}

\begin{abstract}
Franche-Comté is the primary producing region of Protected Designation of Origin cheeses in France. Normally, mid-infrared (MIR) prediction models for cheese-making property (CMP) traits are developed using individual bovine milks. However, considering the requests of all actors in the dairy sector, the present study aimed to assess the feasibility of MIR spectroscopy to develop CMP equations of Montbéliarde herd and dairy vat milks. For this purpose, $22 \mathrm{CMP}$ traits were analyzed on samples collected in 2016 (half in February-March and half in May-June) from 100 commercial herds and 70 dairy vats (55 cheese dairies) located in Franche-Comté. These characteristics included 11 rennet coagulation traits and 8 lactic acidification traits measured in either soft cheese or pressed cooked cheese conditions and 3 laboratory curd yields. Models of MIR prediction for each of the 22 CMP traits were built using partial least squares regression with external validation by dividing the data set into calibration (70\%) and validation (30\%) sets. We confirmed that the variability of milk traits depends largely on the production scale and is higher for individual milk than for herd milk and even higher for vat milk. The best prediction models were obtained in herd milk samples for curd yields expressed in dry matter or fresh, with a coefficient of determination $\left(\mathrm{R}^{2}\right)$ in external validation of 0.78 and 0.77 , respectively. As with individual milk, these traits are closely related to the gross composition of the milk
\end{abstract}

Received August 23, 2019.

Accepted February 19, 2020.

*Current address: Chr. Hansen France, F-25000 Besançon, France.

†Corresponding author: agnes.delacroix-buchet@inrae.fr and therefore easier to predict by MIR spectroscopy. However, these curd yield traits were poorly predicted $\left(R^{2}=0.58\right)$ in vat milk samples due to their lower variability. In herd milk samples, prediction models of other CMP traits were poorly accurate except for the ratio of the time to obtain a standard firmness to the rennet coagulation time in soft cheese or pressed cooked cheese conditions, which showed $\mathrm{R}^{2}>0.66$ in external validation. Such trait is important in qualifying the behavior of milk during cheese production. Prediction models of other CMP traits for either herd or vat milk samples had poor accuracy, and further work is needed to improve their performance.

Key words: cheese-making property, mid-infrared spectroscopy prediction, Montbéliarde herd milk, dairy vat milk, Franche-Comté Protected Designation of Origin cheese

\section{INTRODUCTION}

Managing cheese-making properties (CMP) of milk is important for cheese-makers to secure quality and regularity in cheese production, especially for Protected Designation Origin (PDO) and Protected Geographical Indication (PGI) cheeses, where treatment of milk (e.g., standardization and heating) is limited or forbidden. The Franche-Comté region, located in eastern France, is the primary producing region of PDO cheeses in France (4 PDO cheeses and 1 PGI cheese). Among the 4 PDO cheeses, Comté, the main French PDO cheese (about 60,000 t), is a cooked pressed cheese, Morbier is an uncooked pressed cheese, Mont d'Or (or Vacherin du Haut-Doubs) is a soft cheese with a washed rind, and Bleu de Gex Haut-Jura is a blue-veined cheese. Gruyère, a PGI cheese related to Comté, is a pressed 
cooked cheese. Like many long-life mountain cheeses, Comté is a large cheese. Approximately $400 \mathrm{~L}$ of raw milk is needed to produce a Comté cheese wheel with an average final weight of $40 \mathrm{~kg}$. The PDO cheese sector in Franche-Comté bands together producers, cheese-makers, and cheese ripeners. Local producers pool the milk from their herds in a shared processing unit, a small cooperative called a "fruitière," to produce PDO and PGI cheeses from whole raw milk according to strict specifications. The average total volume of vats is about $3,500 \mathrm{~L}$ in a fruitière. This old cooperative system, dating back to the Middle Ages, to this day makes Comté a cheese with strong roots. Professionals in the sector raise questions about the effects of blending milks with different CMP and storage conditions on the properties of the mixture, which is processed into cheese. Studies on this subject are rare and focus on several specific features, such as the effect of mixing milks of different breeds (Bland et al., 2015a,b), normal and abnormal milks (O'Brien et al., 2001; Frederiksen et al., 2011), or milks from different calving seasons (Lin et al., 2017) as well as the effect of milk storage conditions (Summer et al., 2006; Malacarne et al., 2013; O'Connell et al., 2017). In practice, field studies are difficult, expensive, and time consuming when requiring gold standard methods. Few studies have investigated the variation of milk technological traits at a level other than the individual. These studies were mainly conducted at the herd level (De Marchi et al., 2007; Summer et al., 2014; Penasa et al., 2016) and some at the cheese vat level but in only a small number of commercial cheese factories (Malacarne et al., 2006; Summer et al., 2015).

For some years, mid-infrared (MIR) spectroscopy appeared to be an easy, fast, and cost-effective method for milk phenotyping in the dairy industry (De Marchi et al., 2014, 2018). Since 2015, the laboratory of the Trentingrana-Consorzio dei Caseifici Sociali Trentini s.c.a. (Trento, Italy) has adopted MIR spectroscopy to predict the coagulating ability of bulk milk samples routinely collected from each associated herd (Benedet et al., 2018). Over the past decade, numerous studies have been published on the ability of MIR spectroscopy to assess CMP traits of individual milk (Dal Zotto et al., 2008; De Marchi et al., 2009; Visentin et al., 2015), but studies on bulk milk are recent, rare, and limited. Benedet et al. (2018) used MIR predictions available on MilkoScan FT6000 (Foss, Hillerød, Denmark) to assess technological traits of herd bulk milk in their study, and Manuelian et al. (2019) developed MIR models to predict coagulation and acidity traits of sheep bulk milk. In a previous study (El Jabri et al., 2019), we examined the feasibility of using MIR spectroscopy to predict CMP (rennet coagulation, acidification by lactic bacteria, and laboratory curd yield, CY) of individual French
Montbéliarde milks (I-milk) from the Franche-Comté cheese production area, comparing partial least squares (PLS) and Bayesian methods. In our case, we obtained the best predictions using PLS regression. Considering the requests of all actors in the dairy sector, we conducted a study at 2 other production scales - herd tank milk (H-milk) and dairy vat milk (V-milk) - to evaluate the feasibility of developing CMP predictions of Montbéliarde H-milk and V-milk and to compare prediction results at different production scales.

\section{MATERIALS AND METHODS}

\section{Sampling Criteria and Protocol}

We selected and collected a range of PDO milks (Hmilk and V-milk) as wide as possible. A total of 100 commercial herds were selected from an initial data set of 2,100 PDO and PGI herds of Franche-Comté. Herd selection was carried out to hedge the variability of the dairy farming practices in natural geographic location (plain, first plateau, second plateau, and mountain), calving season (autumn, late winter/early spring, summer), and average annual herd protein content based on the previous milking campaign data recording $(<3.2,3.2-3.3,3.3-3.4$, and $>3.4 \%$; Supplemental Table S1, https://doi.org/10.3168/jds.2019-17491). The milk-cooling tank of these 100 commercial herds was half sampled in February to March 2015 and half sampled in May to June 2015. The average lactation ranks and average calving months of the sampled herds were representative of those in the Franche-Comté PDO zone (Supplemental Figure S1, https://doi.org/ 10.3168/jds.2019-17491). Samples were collected from the tank containing 2 successive milkings, except on farms where the milk is delivered to the dairy after each milking (lait de coulée). In this case, the herd tank was sampled twice; namely, 2 samples of 2 consecutive milkings were collected and then mixed in proportion of each milking volume. Seventy dairy vats were sampled (before starter addition) at the same periods as herd tank milks in 57 dairy cooperatives located in the PDO cheese area, including 13 dairies that were collected in both periods. The milk delivered to the dairies was refreshed at $12^{\circ} \mathrm{C}$ for 12 to $24 \mathrm{~h}$ in accordance with the PDO specifications. Dairies were selected to maximize the expected milk composition variability in altitude of the collection area $(<400,400-700,700-1,000$, and $>1,000 \mathrm{~m})$ and dairy size $(<10,10-15,16-25$, and $>25$ milk producers; Supplemental Table S2, https:// doi.org/10.3168/jds.2019-17491). Cows located in 216 single-breed commercial herds were selected according to their lactoprotein phenotypes and lactation stages to reflect the diversity of Montbéliarde milk composition 
in Franche-Comté. A total of 250 I-milk samples were collected in 2016, half in January to March (indoor season) and half in April to June (grazing outdoor season), from the morning milking $(2 / 5)$, the evening milking $(2 / 5)$, or the mixture of 2 successive milkings in relative proportion (1/5; El Jabri et al., 2019). Animals, herds, and dairies were selected independently and in a manner that was representative across the 3 departments (Doubs, Jura, and Haute-Saône) of the Franche-Comté region.

\section{Milk Analysis}

Milk analyses, MIR spectra acquisition, and PLS calibration equation development were performed as previously described in detail for I-milk (El Jabri et al., 2019). In short, every representative sample of fresh raw whole milk was collected under strict hygienic conditions, immediately cooled to $4^{\circ} \mathrm{C}$, divided into 2 subsamples, and analyzed within $24 \mathrm{~h}$. One subsample was preserved with bronopol and analyzed by MIR spectroscopy using a MilkoScan FT6000 (Foss) and by Fossomatic FC counter (Foss) for SCC (Lacolait, Roulans, France). We recorded fat, protein, lactose, and urea contents; MIR spectra were stored. The second subsample was analyzed for total viable counts (cfu/ $\mathrm{mL}$ ), microbial quality (resazurin, natural lactofermentation), titratable acidity (TA), and coagulation and acidification properties (Enilbio, Poligny, France) according to the reference methods for soft cheese (SC) and pressed cooked cheese (PCC) technology as well as CY traits (INRAE, Poligny, France). Milk with SCC $>10^{6} / \mathrm{mL}$ and cfu $>10^{5} / \mathrm{mL}$ was discarded. Twentytwo CMP traits were measured, including 11 rennet coagulation traits, 8 lactic acidification traits, and 3 laboratory CY (El Jabri et al., 2019).

Microbial Quality Tests. We performed 2 tests commonly used to characterize the cheese-making value of milk from a microbiological viewpoint. The resazurin test is a colorimetric redox test in which milk and resazurin redox indicator are incubated in the dark at $37^{\circ} \mathrm{C}$ and reading is done after 4 and $6 \mathrm{~h}(6=$ nondiscolored and $0=$ totally discolored). The lactofermentation test is a natural fermentation test in which milk is incubated in the dark at $37^{\circ} \mathrm{C}$ and milk $\mathrm{pH}$ and aspect (e.g., liquid, homogeneous gel, flaky gel, contracted gel, swollen gel, or digested gel) are recorded after $24 \mathrm{~h}$. It allows hypotheses to be made about the prevalence of spoilage microflora and the overall microbial load of milks and the acidification capacity of milks to be measured.

Coagulation Traits. Coagulation properties were measured with the Formoptic, adapted from a Formagraph (Foss Electric) by Chr. Hansen (Horshom, Den- mark) and Enilbio (Poligny, France) to improve data computerization. In short, raw whole milk samples (10 $\mathrm{mL}$ ) adjusted in $\mathrm{pH}$ (6.45 in $\mathrm{SC}$ conditions or 6.60 in PCC conditions) were coagulated at $32^{\circ} \mathrm{C}$ with Naturen rennet extract (Chr. Hansen, Arpajon, France) in SC conditions or Berthelot rennet extract (ABIA, Beaune, France) in PCC conditions. Both tests were performed in duplicate. With the Formoptic, an optical sensor measures the pendulum movement and converts this information into voltages. These measures are computerized, and a specific software program creates a diagram of firmness (expressed in firmness index, FI; FI $=$ volts $\times 10$ ) versus time (in min). From this diagram, we recorded the following coagulation traits:

1. rennet coagulation time to $0.5 \mathrm{FI}$ for $\mathrm{SC}$ $\left(\mathbf{R C T}_{\mathbf{S C}}\right)$ and PCC $\left(\mathbf{R C T}_{\mathbf{P C C}} ; \min \right)$,

2. curd firmness after RCT for $\mathrm{SC}\left(\mathbf{a}_{\mathbf{S C}}\right)$ and PCC ( $\mathbf{a}_{\mathrm{PCC}}$; FI units),

3. curd firmness at 2 times RCT for SC $\left(\mathrm{a} 2_{\mathrm{SC}}\right.$; FI units),

4. time to obtain $10 \mathrm{FI}$ from RCT for $\mathrm{SC}\left(\mathrm{K} 10_{\mathrm{SC}}\right)$ and $\mathrm{PCC}\left(\mathrm{K} 10_{\mathrm{PCC}} ; \mathrm{min}\right)$,

5. the ratio of the time to obtain a standard firmness $(\mathbf{K 1 0})$ to $\mathrm{RCT}$ for $\mathrm{SC}\left(\mathbf{K} \mathbf{1 0} / \mathbf{R C T}_{\mathbf{S C}}\right)$ and PCC $\left(\mathbf{K} 10 / \mathbf{R C T}_{\mathbf{P C C}}\right)$, and

6. the curd organization speed (TG10; slope of the curve at firmness $=10 \mathrm{FI})$ for $\mathrm{SC}\left(\mathrm{TG} 10_{\mathrm{SC}}\right)$ and PCC (TG10 $\left.{ }_{\mathrm{PCC}}\right)$.

Acidity Traits. The CINAC system (Corrieu et al., 1988) was used to assess the acidification properties of milk by continuous measurement of $\mathrm{pH}$ for $20 \mathrm{~h}$ in either SC or PCC conditions. Flasks of raw whole milk $(100 \mathrm{~mL})$ were either inoculated $\left(5.10^{6}-10^{7} \mathrm{cfu} / \mathrm{mL}\right.$ of milk) with a mesophilic starter (Lactococcus lactis ssp. lactis) and submitted to a specific SC time-temperature combination or inoculated $\left(5.10^{6}-10^{7} \mathrm{cfu} / \mathrm{mL}\right.$ of milk) with a thermophilic starter (Streptococcus thermophilus) and submitted to a specific PCC time-temperature combination. We conducted the 2 tests in parallel on 2 systems. We recorded the following cheese-specific traits:

1. initial $\mathrm{pH}$ for $\mathrm{SC}\left(\mathbf{p H}_{\mathbf{0 S C}}\right)$ and $\mathrm{PCC}\left(\mathbf{p H}_{\mathbf{0 P C C}}\right.$; in $\mathrm{pH}$ units, upH),

2. acidification rate from 170 to $230 \mathrm{~min}$ for PCC $\left(\mathbf{A R}_{170-230 \mathrm{PCC}} ; \mathrm{upH} / \mathrm{h}\right)$

3. $\mathrm{pH}$ at $10 \mathrm{~h}$ for PCC $\left(\mathrm{pH}_{10 \mathrm{hPCC}} ; \mathrm{upH}\right)$,

4. time to reach a decrease of $0.08 \mathrm{upH}$ from initial $\mathrm{pH}$ for $\mathrm{SC}\left(\mathrm{T} \Delta \mathrm{pH}_{0.08 \mathrm{SC}} ; \mathrm{h}\right)$,

5. time from $\mathrm{pH} 6$ to $\mathrm{pH} 4.8$ for $\mathrm{SC}\left(\mathbf{T} \boldsymbol{\Delta} \mathbf{p} \mathbf{H}_{6-4.8 \mathrm{SC}}\right.$; h), 
6. decrease in $\mathrm{pH}$ from 16 to $20 \mathrm{~h}$ for $\mathrm{SC}$ $\left(\Delta \mathrm{pH}_{16-20 \mathrm{hSC}} ; \mathrm{upH}\right)$, and

7. $\mathrm{pH}$ at $20 \mathrm{~h}$ for $\mathrm{SC}\left(\mathrm{pH}_{20 \mathrm{hSC}} ; \mathrm{upH}\right)$.

CY Traits. Finally, laboratory CY were measured in duplicate according to a method adapted from Hurtaud et al. (1993). A rennet extract (Berthelot, ABIA) was added to raw whole milk samples $(50 \mathrm{~mL}$ in conical centrifuge tube at $\mathrm{pH} 6.6$ and $32^{\circ} \mathrm{C}$ ). One hour after rennet addition, the coagulum was cut and then centrifuged $\left(2,700 \times g\right.$ for $15 \mathrm{~min}$ at $\left.32^{\circ} \mathrm{C}\right)$. The supernatant (whey) was carefully recovered. Milk, curd, and whey were weighed. We determined the DM of the milk and the whey (NF V04-294 standard, 1996) and the protein content and fat content of the milk (MIR spectroscopy) and calculated the following CY:

1. fresh CY $\left(\mathbf{C Y}_{\mathrm{FRESH}} ; \%\right)$ : $\mathrm{CY}_{\mathrm{FRESH}}=100 \times(\mathrm{g}$ of curd/g of milk);

2. $\mathrm{CY}$ in $\mathrm{DM}\left(\mathbf{C Y}_{\mathrm{DM}} ; \%\right): \mathrm{CY}_{\mathrm{DM}}=100 \times[1-(\mathrm{g}$ $\mathrm{DM}$ of whey/g DM of milk)];

3. $\mathrm{CY}$ in fat and protein $\left(\mathbf{C Y}_{\text {FAT-PROT }} ; \mathrm{g} / \mathrm{kg}\right.$; the amounts of milk fat and protein required to obtain $1 \mathrm{~kg}$ of curd): $\mathrm{CY}_{\text {FAT-PROT }}=$ (protein content + fat content $) \times(\mathrm{g}$ of milk/g of curd $)$.

\section{MIR Spectra and Prediction Models}

Mid-infrared spectra were collected over the spectral range from wavenumbers 5,011 to $925 \mathrm{~cm}^{-1}$, standardized (Grelet et al., 2015), and cleared from spectra regions tainted by the water absorbance following Foss recommendations. Calibration equations were developed on 446 informative wavelengths for each of the 22 CMP traits using a PLS approach with external validation by dividing the data set into calibration (70\%) and validation (30\%) sets after outlier elimination. Outliers were discarded from reference data using the Grubbs test (Grubbs, 1969). The optimal number

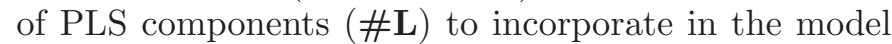
was defined by evaluating the root mean squared error of prediction based on cross-validation. We carried out PLS regression analyses on the H-milk sample data set $(\mathrm{n}=100)$, on the V-milk sample data set $(\mathrm{n}=70)$, then on the H-milk $+\mathrm{V}$-milk sample data set $(\mathrm{n}=$ 170), and finally on the entire data set (all samples: I-milk $+\mathrm{H}$-milk $+\mathrm{V}$-milk samples, $\mathrm{n}=420$ ). To assess and compare the equations, statistical parameters were calculated: mean, standard deviation (SD), coefficient of determination $\left(\mathbf{R}^{2}\right)$, residual standard deviation $\left(\mathbf{S}_{\mathbf{y}, \mathbf{x}}\right)$, relative error $\left(\mathbf{R S}_{\mathbf{y}, \mathbf{x}}\right.$; ratio of the residual standard deviation to the reference mean, in \%), bias (mean of differences between predicted and observed values), accuracy $\left(2 \times \mathrm{S}_{\mathrm{y}, \mathrm{x}}\right.$ corresponds to the accuracy limits: $95 \%$ of residuals are between $\pm 2 \times \mathrm{S}_{\mathrm{y}, \mathrm{x}}$; ISO, 2009 ), and ratio to performance deviation of external validation (RPD; ratio of SD of the reference data to standard error of prediction; El Jabri et al., 2019). We used R software (version 3.2.3., https://r-project.org/ ) for all computation. Equations with the lowest $R S_{y, x}$ and the highest $\mathrm{R}^{2}$ and $\mathrm{RPD}$ values were regarded as being the most accurate (Coppa et al., 2010; FerrandCalmels et al., 2014). Coppa et al. (2010) used the $\mathrm{R}^{2}$ value to define 4 classes of robustness: excellent $\left(\mathrm{R}^{2} \geq\right.$ $0.91)$, good $\left(0.82<\mathrm{R}^{2}<0.90\right)$, approximate $(0.66<$ $\left.\mathrm{R}^{2}<0.81\right)$, and poor $\left(\mathrm{R}^{2}<0.66\right)$. Equations with $\mathrm{RPD}$ $>2$ enable predictions with good accuracy (De Marchi et al., 2013; Gottardo et al., 2015). Viscarra Rossel et al. (2006) defined more specifically 6 classes: excellent $(\mathrm{RPD}>2.5)$, very good $(2<\mathrm{RPD}<2.5)$, good $(1.8$ $<\mathrm{RPD}<2)$, fair $(1.4<\mathrm{RPD}<1.8)$, poor $(1<\mathrm{RPD}$ $<1.4)$, and very poor $(\mathrm{RPD}<1)$.

\section{RESULTS AND DISCUSSION}

\section{Characterization of Milk Samples}

Composition Traits. Table 1 summarizes the descriptive statistics for milk composition and CMP traits of I-milk, H-milk, and V-milk samples. The milk's average chemical composition and variability were consistent with the data from routine milk recordings at the same periods and for each production scale in the Franche-Comté region. Not surprisingly, the variability of these traits depended largely on the production scale and was highest for I-milk and lowest for V-milk. The coefficient of variation (CV) of all measured traits decreased rapidly from I-milk to H-milk and V-milk. Mean values for the composition traits were quite similar at all 3 production scales. This was especially true for protein, urea, $\mathrm{pH}$, and TA, which averaged 3.23\%, 26.6 $\mathrm{mg} / 100 \mathrm{~mL}, 6.74$, and $16.3^{\circ} \mathrm{D}$, respectively. The average TA for H-milk was similar to that routinely collected on herds in Italy and in recent years $\left(3.42-3.62^{\circ} \mathrm{SH} / 50 \mathrm{~mL}\right.$ equivalent to $15.4-16.3^{\circ} \mathrm{D}$; Penasa et al., 2016; Benedet et al., 2018). Concerning PDO cheese V-milk, studies on Parmigiano-Reggiano V-milk from pure-breed herds (Italian Friesian or Italian Brown) reported for $\mathrm{pH}$ mean and SD values similar to ours (6.71-6.74, $\mathrm{SD}=0.03-0.04)$ and for TA lower mean values (3.17-

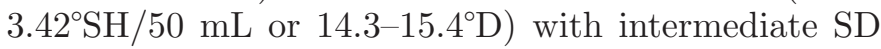
$\left(0.11-0.15^{\circ} \mathrm{SH} / 50 \mathrm{~mL}\right.$ or $0.50-0.68^{\circ} \mathrm{D}$; Malacarne et al., 2006; Summer et al., 2015). Differences in TA values between V-milks can be related to the cow breeds or the fact that Parmigiano-Reggiano is made of skim milk from the evening milking and whole milk from the morning milking. Fat and fat/protein ratio were on average slightly lower in H-milk and V-milk $(3.74 \%$ 
and 1.16 for H-milk; $3.67 \%$ and 1.14 for V-milk) than in I-milk (3.80\% and 1.18). In contrast, SCS and total viable counts were higher in H-milk (3.51, 3.73 log cfu/ $\mathrm{mL})$ and V-milk $(3.86,4.44 \log \mathrm{cfu} / \mathrm{mL})$ than in I-milk $(2.21,3.38 \mathrm{log} \mathrm{cfu} / \mathrm{mL})$ but still at levels low enough to be considered good-quality milk, as confirmed by the resazurin and lactofermentation tests. The average value and SD for SCS and total viable counts in H-milk were of the same order or less than results reported in milks collected in herds from other PDO cheese areas (Penasa et al., 2016).

CMP Traits. In all data $(\mathrm{n}=420$; not shown in Table 1), the $\mathrm{CV}$ for $\mathrm{CY}_{\mathrm{DM}}$, $\mathrm{a}_{\mathrm{SC}}$, and $\mathrm{a}_{\mathrm{PCC}}$ averaged 8.0, 14.2 , and $14.0 \%$, respectively, but CV in H-milk were less than half those in I-milk $(3.5,7.0$, and $7.2 \%$ vs. $9.9,17.5$, and $17.5 \%$, respectively) and even lower in V-milk (2.4,6.2, and 5.0\%, respectively). The CY mean values in $\mathrm{H}$-milk or $\mathrm{V}$-milk, regardless of their mode of

Table 1. Descriptive statistics of composition and cheese-making property traits obtained by reference methods of individual ( $\mathrm{n}=250$ ), herd tank $(\mathrm{n}=100)$, and dairy vat $(\mathrm{n}=70)$ milk samples

\begin{tabular}{|c|c|c|c|c|c|c|c|c|c|c|c|c|}
\hline \multirow[b]{2}{*}{ Trait $^{1}$} & \multicolumn{4}{|c|}{ Individual cow } & \multicolumn{4}{|c|}{ Herd tank } & \multicolumn{4}{|c|}{ Dairy vat } \\
\hline & $\mathrm{n}^{2}$ & Mean & $\mathrm{SD}$ & $\mathrm{CV}(\%)$ & $\mathrm{n}^{2}$ & Mean & $\mathrm{SD}$ & $\mathrm{CV}(\%)$ & $\mathrm{n}^{2}$ & Mean & $\mathrm{SD}$ & $\mathrm{CV}(\%)$ \\
\hline \multicolumn{13}{|l|}{ Milk characteristics } \\
\hline Fat $(\%)$ & 250 & 3.80 & 0.76 & 19.92 & 100 & 3.74 & 0.21 & 5.64 & 70 & 3.67 & 0.13 & 3.56 \\
\hline Protein $(\%)$ & 250 & 3.24 & 0.37 & 11.33 & 100 & 3.23 & 0.14 & 4.36 & 70 & 3.22 & 0.09 & 2.81 \\
\hline Fat:protein ratio & 250 & 1.18 & 0.23 & 19.25 & 100 & 1.16 & 0.08 & 6.96 & 70 & 1.14 & 0.05 & 4.31 \\
\hline Lactose $(\%)$ & 250 & 4.86 & 0.22 & 4.43 & 100 & 4.91 & 0.07 & 1.49 & 70 & 4.89 & 0.05 & 1.08 \\
\hline Urea (mg/100 mL) & 250 & 26.58 & 7.88 & 29.65 & 100 & 26.59 & 7.40 & 27.84 & 70 & 26.64 & 4.22 & 15.86 \\
\hline $\mathrm{pH}$ & 250 & 6.75 & 0.06 & 0.84 & 100 & 6.74 & 0.03 & 0.43 & 70 & 6.74 & 0.03 & 0.43 \\
\hline Titratable acidity $\left({ }^{\circ} \mathrm{D}\right)$ & 250 & 16.32 & 1.42 & 8.67 & 100 & 16.50 & 0.86 & 5.24 & 70 & 16.17 & 0.57 & 3.53 \\
\hline $\mathrm{SCS}^{3}$ & 250 & 2.21 & 1.72 & 77.86 & 100 & 3.51 & 0.86 & 24.52 & 70 & 3.86 & 0.45 & 11.60 \\
\hline Total viable counts $(\log \mathrm{cfu} / \mathrm{mL})$ & 250 & 3.38 & 0.66 & 19.41 & 100 & 3.73 & 0.56 & 15.14 & 70 & 4.44 & 0.50 & 11.15 \\
\hline $\begin{array}{l}\text { Resazurin test value } 4 \mathrm{~h} \text { after redox } \\
\text { indicator addition }\end{array}$ & 250 & 5.43 & 0.50 & 9.28 & 100 & 5.82 & 0.32 & 5.42 & 69 & 5.44 & 0.55 & 10.03 \\
\hline $\begin{array}{l}\text { Resazurin test value } 6 \mathrm{~h} \text { after redox } \\
\text { indicator addition }\end{array}$ & 250 & 5.01 & 0.76 & 15.09 & 100 & 5.47 & 0.57 & 10.42 & 66 & 4.64 & 0.77 & 16.66 \\
\hline $\begin{array}{l}\text { Lactofermentation test } \mathrm{pH} \text { after } 24-\mathrm{h} \\
\text { raw milk incubation }\end{array}$ & 250 & 5.82 & 0.64 & 11.02 & 100 & 5.20 & 0.51 & 9.83 & 70 & 4.44 & 0.25 & 5.58 \\
\hline \multicolumn{13}{|l|}{ Coagulation traits for $\mathrm{SC}$ at $\mathrm{pH} 6.45$} \\
\hline $\mathrm{RCT}_{\mathrm{SC}}(\mathrm{min})$ & 250 & 17.00 & 3.55 & 20.90 & 92 & 17.28 & 1.65 & 9.57 & 68 & 17.50 & 2.09 & 11.97 \\
\hline $\mathrm{K} 10_{\mathrm{SC}}(\mathrm{min})$ & 247 & 6.57 & 2.22 & 33.77 & 92 & 5.73 & 0.90 & 16.74 & 68 & 5.75 & 0.94 & 16.34 \\
\hline $\mathrm{K} 10 / \mathrm{RCT}_{\mathrm{SC}}$ & 249 & 0.40 & 0.13 & 32.02 & 92 & 0.33 & 0.05 & 14.37 & 68 & 0.33 & 0.04 & 12.99 \\
\hline $\mathrm{a}_{\mathrm{SC}}(\mathrm{FI})$ & 250 & 18.79 & 3.29 & 17.49 & 92 & 19.44 & 1.37 & 7.04 & 68 & 19.58 & 1.22 & 6.23 \\
\hline $\mathrm{a} 2_{\mathrm{SC}}(\mathrm{FI})$ & 250 & 22.86 & 2.68 & 11.74 & 92 & 23.12 & 1.18 & 5.12 & 68 & 23.30 & 1.01 & 4.34 \\
\hline TG10 $10_{\mathrm{SC}}$ & 248 & 14.31 & 5.54 & 38.73 & 92 & 14.00 & 2.43 & 17.39 & 68 & 14.06 & 2.36 & 16.79 \\
\hline \multicolumn{13}{|l|}{ Coagulation traits for $\mathrm{PCC}$ at $\mathrm{pH} 6.60$} \\
\hline $\mathrm{RCT}_{\mathrm{PCC}}(\mathrm{min})$ & 249 & 31.86 & 7.29 & 22.86 & 100 & 31.01 & 2.43 & 7.83 & 68 & 31.80 & 3.28 & 10.30 \\
\hline $\mathrm{K} 10_{\mathrm{PCC}}(\mathrm{min})$ & 246 & 12.65 & 4.85 & 38.29 & 94 & 10.48 & 1.78 & 17.02 & 68 & 10.97 & 1.78 & 16.23 \\
\hline $\mathrm{K} 10 / \mathrm{RCT}_{\mathrm{PCC}}$ & 248 & 0.40 & 0.13 & 31.79 & 96 & 0.34 & 0.05 & 14.90 & 68 & 0.34 & 0.04 & 10.63 \\
\hline $\mathrm{a}_{\mathrm{PCC}}(\mathrm{FI})$ & 249 & 18.42 & 3.22 & 17.47 & 96 & 18.98 & 1.37 & 7.22 & 68 & 18.96 & 0.95 & 5.00 \\
\hline TG10 $\mathrm{PCC}$ & 246 & 7.32 & 3.17 & 43.31 & 96 & 7.44 & 1.43 & 19.22 & 68 & 7.13 & 1.18 & 16.49 \\
\hline \multicolumn{13}{|l|}{ Acidification traits for SC } \\
\hline $\mathrm{pH}_{0 \mathrm{SC}}(\mathrm{upH})$ & 250 & 6.58 & 0.08 & 1.19 & 95 & 6.64 & 0.04 & 0.62 & 67 & 6.64 & 0.03 & 0.52 \\
\hline $\mathrm{T} \Delta \mathrm{pH}_{0.08 \mathrm{SC}}(\mathrm{h})$ & 248 & 3.48 & 0.28 & 8.12 & 95 & 3.48 & 0.34 & 9.79 & 66 & 3.45 & 0.37 & 10.85 \\
\hline $\mathrm{T} \Delta \mathrm{pH}_{6-4.8 \mathrm{SC}}(\mathrm{h})$ & 249 & 6.08 & 1.48 & 24.31 & 96 & 5.16 & 1.03 & 19.96 & 65 & 4.39 & 0.55 & 12.41 \\
\hline$\Delta \mathrm{pH}_{16-20 \mathrm{hSC}}(\mathrm{upH})$ & 250 & 0.20 & 0.15 & 75.34 & 94 & 0.13 & 0.07 & 49.54 & 64 & 0.08 & 0.02 & 28.31 \\
\hline $\mathrm{pH}_{20 \mathrm{hSC}}(\mathrm{upH})$ & 248 & 4.49 & 0.09 & 2.05 & 96 & 4.50 & 0.07 & 1.54 & 65 & 4.45 & 0.04 & 0.88 \\
\hline \multicolumn{13}{|l|}{ Acidification traits for PCC } \\
\hline $\mathrm{pH}_{0 \mathrm{PCC}}(\mathrm{upH})$ & 250 & 6.53 & 0.06 & 0.91 & 91 & 6.55 & 0.04 & 0.55 & 64 & 6.58 & 0.03 & 0.53 \\
\hline $\mathrm{AR}_{170-230 \mathrm{PCC}}(\mathrm{upH})$ & 250 & 0.12 & 0.05 & 37.86 & 92 & 0.12 & 0.03 & 20.63 & 62 & 0.13 & 0.02 & 14.39 \\
\hline $\mathrm{pH}_{10 \mathrm{hPCC}}(\mathrm{upH})$ & 250 & 5.58 & 0.18 & 3.28 & 92 & 5.41 & 0.11 & 2.07 & 62 & 5.40 & 0.08 & 1.51 \\
\hline \multicolumn{13}{|l|}{ Curd yield } \\
\hline Fresh curd yield (\%) & 250 & 38.00 & 9.37 & 24.67 & 100 & 36.06 & 3.63 & 10.06 & 70 & 34.10 & 2.43 & 7.12 \\
\hline Curd yield in DM (\%) & 250 & 66.79 & 6.62 & 9.91 & 100 & 65.71 & 2.31 & 3.51 & 70 & 64.64 & 1.57 & 2.43 \\
\hline Curd yield in fat and protein $(\mathrm{g} / \mathrm{kg})$ & 250 & 191.02 & 26.40 & 13.82 & 100 & 194.90 & 15.65 & 8.03 & 70 & 202.64 & 12.25 & 6.05 \\
\hline
\end{tabular}

${ }^{1} \mathrm{SC}=$ soft cheese; $\mathrm{RCT}=$ rennet coagulation time at $0.5 \mathrm{FI} ; \mathrm{FI}=$ firmness index $(10 \times$ volts $) ; \mathrm{K} 10=$ time to obtain $10 \mathrm{FI}$ from RCT; a $=$ curd

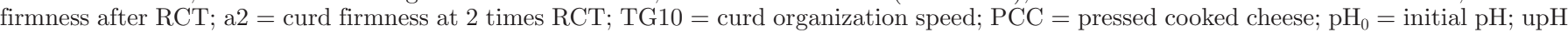
$=\mathrm{pH}$ units; $\mathrm{T} \Delta \mathrm{pH}_{0.08}=$ time to decrease by $0.08 \mathrm{upH}$ from $\mathrm{pH}_{0} ; \mathrm{T} \Delta \mathrm{pH}_{6-4.8}=$ time from $\mathrm{pH} 6$ to $\mathrm{pH} 4.8 ; \Delta \mathrm{pH}$ - $20 \mathrm{~h}=$ decrease in $\mathrm{pH}$ from 16 to $20 \mathrm{~h} ; \mathrm{pH}_{20 \mathrm{~h}}=\mathrm{pH}$ at $20 \mathrm{~h} ; \mathrm{AR}_{170-230}=$ acidification rate from 170 to $230 \mathrm{~min} ; \mathrm{pH}_{10 \mathrm{~h}}=\mathrm{pH}$ at $10 \mathrm{~h}$.

${ }^{2} \mathrm{Number}$ of samples after removing outliers.

${ }^{3} \mathrm{SCS}=\log _{2}(\mathrm{SCC} / 100,000)+3$. 
expression $\left(\mathrm{CY}_{\mathrm{FRESH}}, \mathrm{CY}_{\mathrm{DM}}\right.$, or $\left.\mathrm{CY}_{\mathrm{FAT}-\mathrm{PROT}}\right)$, were lower than those in I-milk, although the curd firmness ( $\mathrm{a}_{\mathrm{SC}}$ or a PCC) was slightly improved in H-milk and V-milk. This is most likely related to the small differences in milk fat recorded between production scales, which slightly and indirectly modify the proportion of protein content when analyzing a fixed volume of whole milk samples. We also noted that $\mathrm{a}_{\mathrm{SC}}$ and $\mathrm{a}_{\mathrm{PCC}}$ means and $\mathrm{CV}$ were similar at a given production scale. Indeed, because of our test conditions (i.e., adjustment of the milk $\mathrm{pH}$ to 6.45 for SC or 6.6 for PCC, followed by a measurement of coagulation traits at $32^{\circ} \mathrm{C}$ with the addition of specific rennet extracts for SC and PCC but an equivalent quantity of chymosin), variations in these traits depend primarily on milk composition (El Jabri et al., 2019). Other coagulation traits (RCT, K10, K10/RCT, and TG10) were half as variable in H-milk or V-milk as in I-milk. Overall, the rennet coagulation traits in H-milk showed less variation than that reported by Toffanin et al. (2012) in 1,570 bulk milk samples collected from 436 Italian dairy herds mainly rearing Holstein-Friesian cows. In this study, the CV of the usual milk coagulation traits [i.e., clotting time, curd firming time $\left(\mathbf{k}_{\mathbf{2 0}}\right)$, and curd firmness $30 \mathrm{~min}$ after rennet addition $\left(\mathbf{a}_{\mathbf{3 0}}\right)$ ] ranged from 20 to $30 \%$, and $4 \%$ of total samples did not coagulate within $30 \mathrm{~min}$. In our case, the conditions ( $\mathrm{pH}$ standardization) and traits (curd firmness after RCT) for measuring rennet coagulation ability have contributed to the reduction of the variability of the traits. Moreover, variations in H-milk and V-milk traits are reduced due to the blending of milks from different cows and herds (Toffanin et al., 2012). However, K10 and TG10 were the most variable coagulation traits $(\mathrm{CV}>15 \%)$ regardless of the production scale. Malacarne et al. (2006) also reported large variability of $\mathrm{k}_{20}(\mathrm{CV}=15-23 \%)$ compared with clotting time $(\mathrm{CV}=7 \%)$ and $\mathrm{a}_{30}(\mathrm{CV}=13-17 \%)$ in 13 comparisons of Parmigiano-Reggiano V-milk composed of a blend of milks from 2 to 5 pure-breed dairy herds (Italian Brown or Italian Friesian). The averages for K10 and $\mathrm{K} 10 / \mathrm{RCT}$ were lower in H-milk and V-milk compared with I-milk in either SC or PCC conditions, suggesting that the proportion of poorly coagulating cow milks in bulk milks was very low (Frederiksen et al., 2011). As a whole, coagulation properties of H-milk and V-milk (with the exception of RCT) were slightly better and CY were somewhat poorer than those of I-milk. Average acidification traits in I-milk, H-milk, and V-milk samples were similar in PCC conditions. However, 2 kinetic traits in $\mathrm{SC}$ conditions, the time from $\mathrm{pH} 6$ to $4.8\left(\mathrm{~T} \Delta \mathrm{pH}_{6-4.8 \mathrm{SC}}\right)$ and the decrease in $\mathrm{pH}$ from 16 to $20 \mathrm{~h}\left(\Delta \mathrm{pH}_{16-20 \mathrm{hSC}}\right)$, had quite different average values depending on the production scales. On average, $\mathrm{T} \Delta \mathrm{pH}_{6-4.8 \mathrm{SC}}$ was $6.1,5.2$, and $4.4 \mathrm{~h}$ and $\Delta \mathrm{pH}_{16-20 \mathrm{hSC}}$ was $0.20,0.13$, and 0.08 upH for I-milk, H-milk, and Vmilk samples, respectively. These acidification kinetic traits in $\mathrm{SC}$ conditions and the acidification rate from 170 to $230 \mathrm{~min}\left(\mathrm{AR}_{170-230 \mathrm{PCC}}\right)$ in $\mathrm{PCC}$ conditions were also much less variable in $\mathrm{H}$-milk and $\mathrm{V}$-milk samples compared with the individual ones. As indicated by the lactofermentation and resazurin tests, the latter observation seemed related to the presence of a native mesophilic lactic microflora. This one differed in quantity and quality in raw milk samples at the different production scales, whereas the difference in terms of total bacterial counts between I-milk and V-milk did not exceed $1 \log$ unit, and TA was the same. When examining the types of lactofermentation obtained at each production scale, it was found that the proportion of homogeneous gelled milk (regarded as more suitable for cheese-making) was $0.57,0.18$, and 0.08 , whereas that of liquid milk was $0.01,0.66$, and 0.79 for V-milk, Hmilk, and I-milk, respectively (results not shown). This is partly due to the requirements for milk collection in the PDO area $\left(12^{\circ} \mathrm{C}, 12-24 \mathrm{~h}\right)$, which allow the growth of mesophilic lactic bacteria as shown by the effects of storage conditions on microbial development of raw milk (Malacarne et al., 2013). On the other hand, these PDO requirements also preserve the coagulation traits as shown either by the average values we observed for the curd firmness and RCT traits or by the findings of other studies (Summer et al., 2006).

\section{Performances of PLS Regression in External Validation}

Table 2 provides the fitting statistics of the most valuable prediction models for CMP traits. To date, studies on the ability of MIR spectroscopy to predict CMP traits in herd bovine milk and dairy vat milk are scarce. We therefore discuss the results we obtained based on those published, if any, on herd bulk milk of other species or on bovine individual milk samples. Among H-milk traits, the best prediction accuracies were achieved in external validation for $\mathrm{CY}_{\mathrm{DM}}\left(\mathrm{R}^{2}\right.$ $=0.78, \mathrm{RPD}=2.07), \mathrm{CY}_{\mathrm{FRESH}}\left(\mathrm{R}^{2}=0.77, \mathrm{RPD}=\right.$ $2.04), \mathrm{K} 10 / \mathrm{RCT}_{\mathrm{SC}}\left(\mathrm{R}^{2}=0.73, \mathrm{RPD}=1.88\right)$, and $\mathrm{K} 10 /$ $\mathrm{RCT}_{\mathrm{PCC}}\left(\mathrm{R}^{2}=0.68, \mathrm{RPD}=1.73\right)$. The calibration equations were built with an optimal number of PLS components lower for the $\mathrm{K} 10 / \mathrm{RCT}(\# \mathrm{~L}=6)$ than for the CY ( $\# \mathrm{~L}=10-11)$ and with the best $\mathrm{RS}_{\mathrm{y}, \mathrm{x}}$ for $\mathrm{CY}_{\mathrm{DM}}(1.3 \%)$. Considering the other H-milk traits, $\mathrm{a}_{\mathrm{SC}}$, $\mathrm{RCT}_{\mathrm{PCC}}, \mathrm{a}_{\mathrm{PCC}}$, and $\mathrm{CY}_{\mathrm{FAT}-\mathrm{PROT}}$ showed $\mathrm{R}^{2}$ and RPD in external validation close to 0.58 and 1.50 , respectively. These accuracies were higher than the findings related to sheep bulk milk samples collected in 140 flocks in central Italy for $\mathrm{RCT}, \mathrm{k}_{20}$, and $\mathrm{a}_{30}\left(0.02<\mathrm{R}^{2}<0.28\right.$; $1.01<$ RPD $<1.18$; Manuelian et al., 2019). They were 
El Jabri et al.: MID-INFRARED SPECTROMETRY PREDICTION OF CHEESE-MAKING PROPERTIES

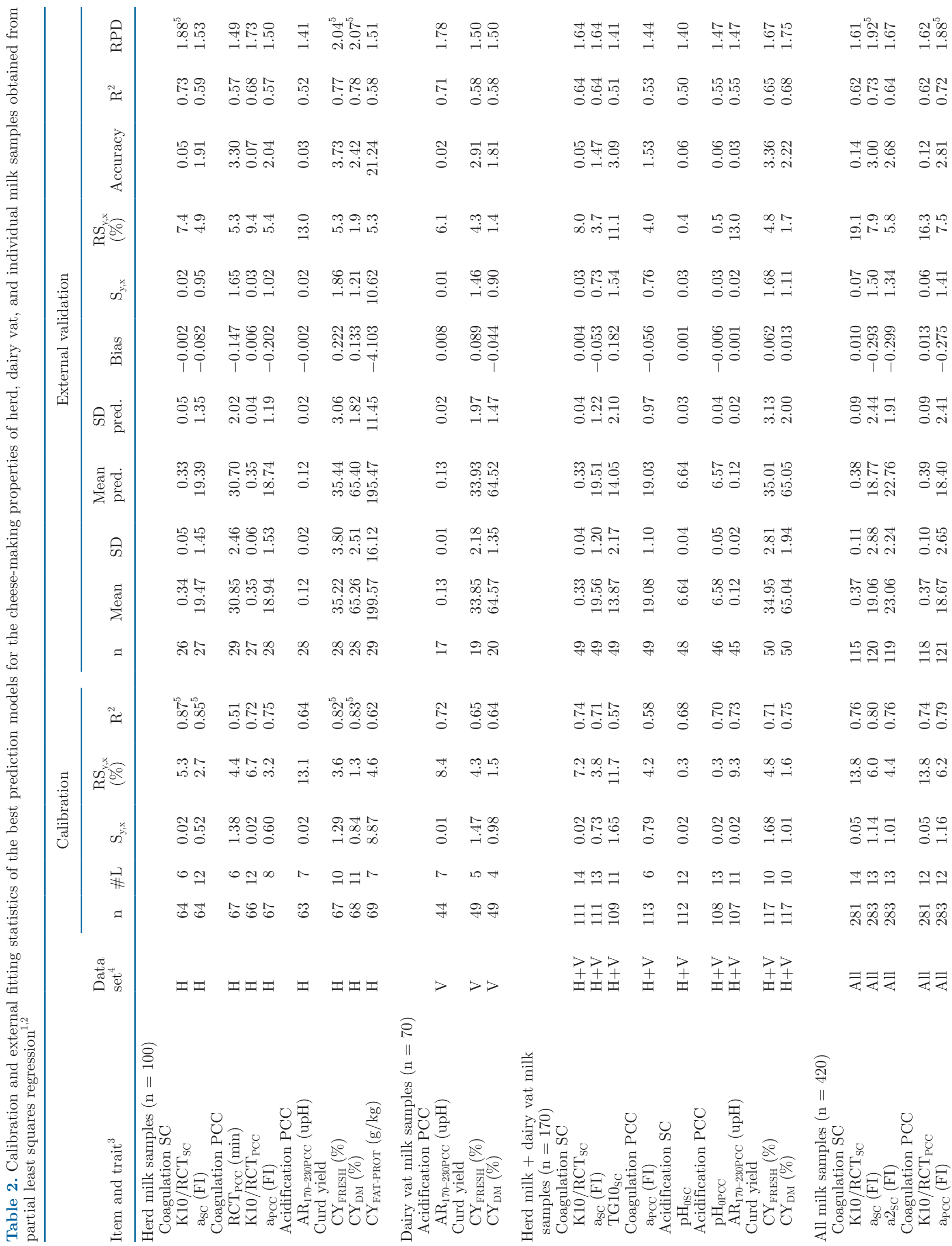




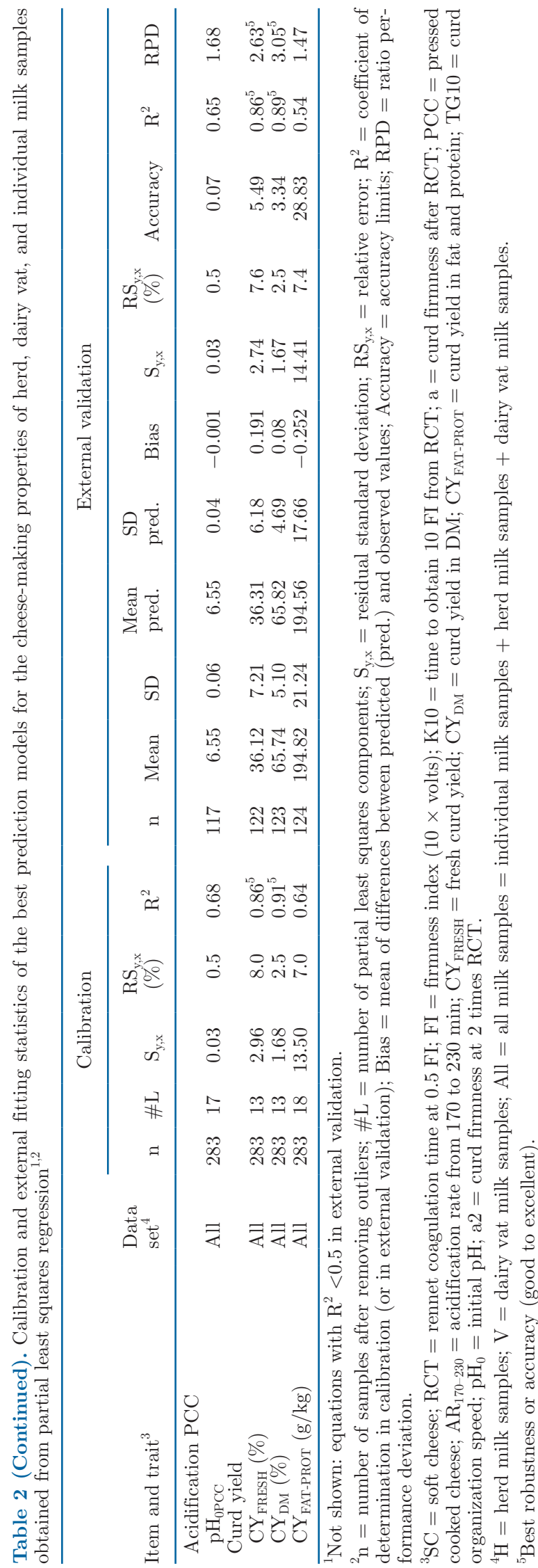

much better for $\mathrm{K} 10 / \mathrm{RCT}_{\mathrm{SC}}\left(\mathrm{R}^{2}:+0.25\right.$ points; $\mathrm{RPD}$ : +0.50 points), $\mathrm{K} 10 / \mathrm{RCT}_{\mathrm{PCC}}\left(\mathrm{R}^{2}:+0.24\right.$ points; $\mathrm{RPD}$ : +0.40 points), and $\mathrm{RCT}_{\mathrm{PCC}}\left(\mathrm{R}^{2}:+0.28\right.$ points; $\mathrm{RPD}$ : +0.31 points), with $\mathrm{RS}_{\mathrm{y}, \mathrm{x}}$ values reduced by half or more compared with the predictions we previously obtained on I-milk in identical analytical conditions (El Jabri et al., 2019). An explanatory element could be a greater homogeneity of the fine composition (i.e., minerals, caseins) of H-milk due to the blending of individual milks. For other CY and coagulation traits, accuracies of MIR predictions on H-milk compared with those found on I-milk were slightly better but still poor for CY $\mathrm{CYAT-PROT}_{\text {F }}$ and were lower for aPCC, $\mathrm{CY}_{\mathrm{FRESH}}$, and $\mathrm{CY}_{\mathrm{DM}}$ but remaining quite good for both $\mathrm{CY}$ (in calibration: $\mathrm{R}^{2}=$ $0.82-0.83$; in external validation: $\mathrm{R}^{2}=0.77-0.78$ and RPD >2.0). In good-quality milk, these traits are mainly correlated with the gross composition of the milk, which is less variable in $\mathrm{H}$-milk and $\mathrm{V}$-milk samples. The best predictions in $\mathrm{V}$-milk traits were achieved for only a few traits: $\mathrm{AR}_{170-230 \mathrm{PCC}}\left(\mathrm{R}^{2}=0.72\right.$ with $\# \mathrm{~L}=7$ in calibration; $\mathrm{R}^{2}=0.71$ and $\mathrm{RPD}=1.78$ in external validation), $\mathrm{CY}_{\mathrm{DM}}$, and $\mathrm{CY}_{\mathrm{FRESH}}\left(\mathrm{R}^{2}=0.64-0.65\right.$ with $\# \mathrm{~L}=4-5$ in calibration; $\mathrm{R}^{2}=0.58$ and $\mathrm{RPD}=1.50$ in external validation). For the first trait, however, the MIR predictive ability was fair. For the last 2 traits, the accuracy of the equations was poor and as low as that of $\mathrm{CY}_{\text {FAT-PROT }}$ in H-milk. The number of samples collected at the dairy vat scale and their reduced variability explain the difficulty of building MIR predictions. By pooling H-milk and V-milk samples $(\mathrm{n}=170)$, we observe a general loss of accuracy of the equations compared with that obtained with the H-milk samples alone. For milk blends, it therefore appears necessary to take into account their intrinsic characteristics, which are partly related to their thermal history. The $\mathrm{pH}_{0 \mathrm{SC}}$ and $\mathrm{pH}_{0 \mathrm{PCC}}$ traits reached $\mathrm{R}^{2}$ values close to 0.7 in calibration as a result of the increased number of data, but $\mathrm{R}^{2}$ values in external validation were not better than 0.55 and 0.50 , respectively. A rather similar observation can be made for the curd organization speed for SC, a coagulation trait measuring the curd organization rate as $\mathrm{K} 10 / \mathrm{RCT}_{\mathrm{SC}}$ but with less accuracy. Finally, by pooling all the data (H-milk + V-milk + I-milk, $\mathrm{n}=420)$, we obtained the most robust and accurate equations in external validation for $\mathrm{CY}_{\mathrm{DM}}\left(\mathrm{R}^{2}=0.89 ; \mathrm{RPD}=3.05\right)$, $\mathrm{CY}_{\text {FRESH }}\left(\mathrm{R}^{2}=0.86 ; \mathrm{RPD}=2.63\right), \mathrm{a}_{\mathrm{SC}}\left(\mathrm{R}^{2}=0.73 ; \mathrm{RPD}\right.$ $=1.92)$, and $\mathrm{a}_{\mathrm{PCC}}\left(\mathrm{R}^{2}=0.72 ; \mathrm{RPD}=1.88\right)$. These 4 CMP traits are among those most closely related to the gross milk composition, and their MIR predictions were calibrated with the most reliable reference methods among those used in this study (El Jabri et al., 2019). By increasing the number of data for these particular traits, we obtained prediction performances in external validation very similar to those obtained previously on 
250 I-milk samples for $\mathrm{CY}_{\mathrm{DM}}\left(\mathrm{R}^{2}:-0.02\right.$ point; RPD: -0.22 point) or even a little better for $\mathrm{CY}_{\mathrm{FRESH}}\left(\mathrm{R}^{2}\right.$ : +0.03 point; RPD: +0.27 point $)$, a $\left(\mathrm{R}^{2}:+0.06\right.$ point; RPD: +0.19 point $)$, and $\mathrm{a}_{\mathrm{PCC}}\left(\mathrm{R}^{2}:+0.09\right.$ point; $\mathrm{RPD}$ : +0.26 point; El Jabri et al., 2019). Figure 1 shows the scatter plots of $\mathrm{CY}_{\mathrm{DM}}, \mathrm{CY}_{\mathrm{FRESH}}$, a $\mathrm{SC}$, and $\mathrm{a}_{\mathrm{PCC}}$ and reports the $\mathrm{R}^{2}$ values obtained with the calibration equation built on all milk samples $(\mathrm{n}=420)$. These plots confirmed that the variability in H-milk and Vmilk was included within the variability measured in
I-milk. Finally, for several traits, we recalculated MIR predictions using for I-milk the calibration equations based on all milk samples $(\mathrm{n}=420)$ and for H-milk or V-milk the calibration equations based on H-milk + V-milk samples $(\mathrm{n}=170)$. On I-milk, we obtained for 6 CMP traits $\left(\mathrm{CY}_{\mathrm{DM}}, \mathrm{CY}_{\mathrm{FRESH}}\right.$, a $\mathrm{aPCC}_{\mathrm{PC}}, \mathrm{a}_{\mathrm{SC}}, \mathrm{a} 2_{\mathrm{SC}}$, and $\left.\mathrm{pH}_{0 \mathrm{PCC}}\right) \mathrm{R}^{2}$ between 0.93 and 0.66 , with $\mathrm{RPD}$ between 3.73 and 1.72. On $\mathrm{H}$-milk, $\mathrm{R}^{2}$ values were poor for all traits $(<0.66)$, and on $\mathrm{V}$-milk, $\mathrm{CY}_{\mathrm{DM}}$ was the only trait reaching fair prediction $\left(\mathrm{R}^{2}=0.68\right.$, with $\left.\mathrm{RPD}=1.75\right)$.

\section{(a) CY FRESH}

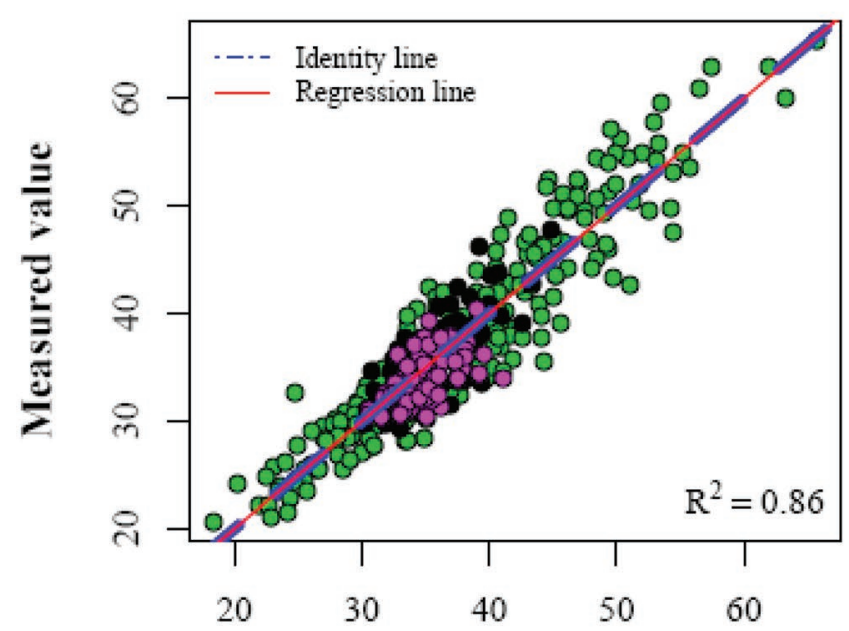

(c) apCc

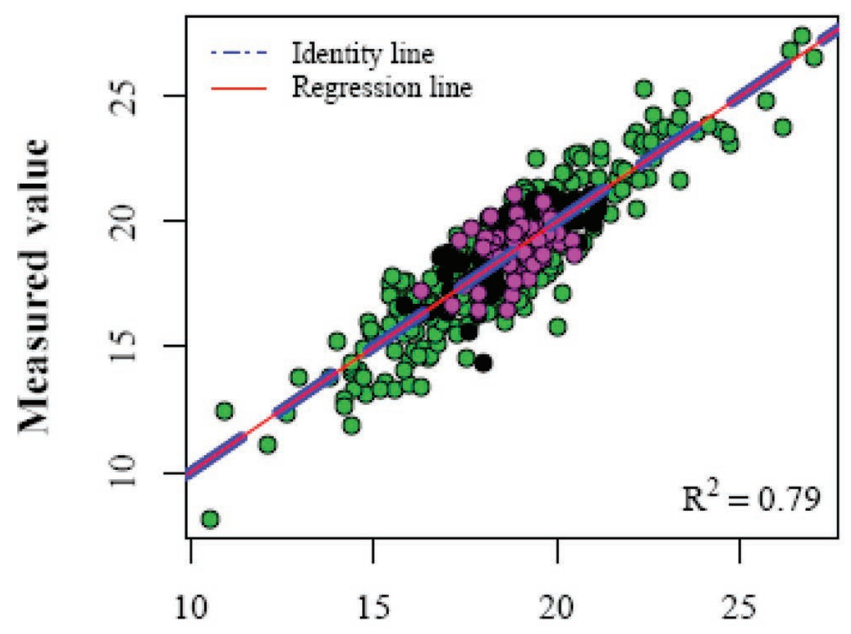

Predicted value

\section{(b) $\mathrm{CY}_{\mathrm{DM}}$}

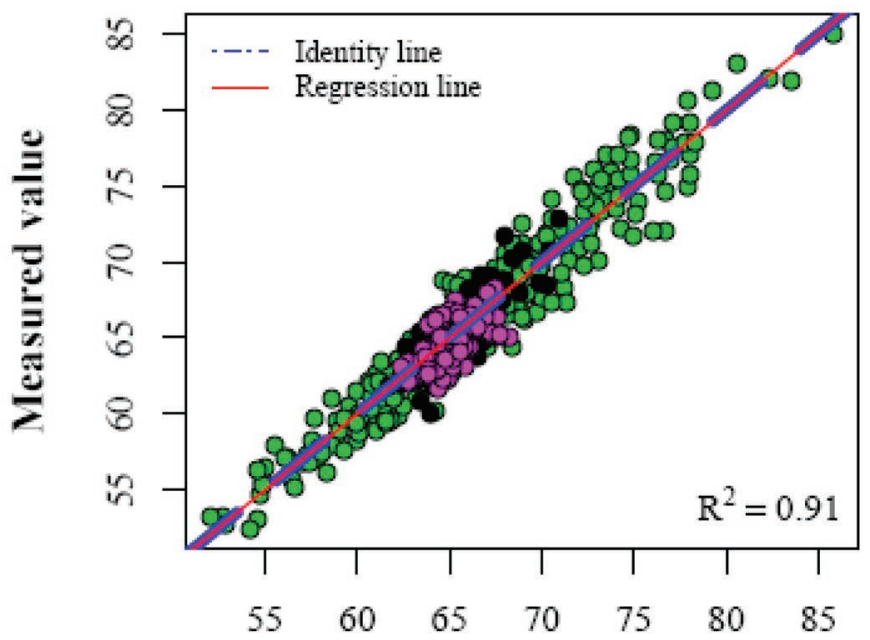

(d) asc

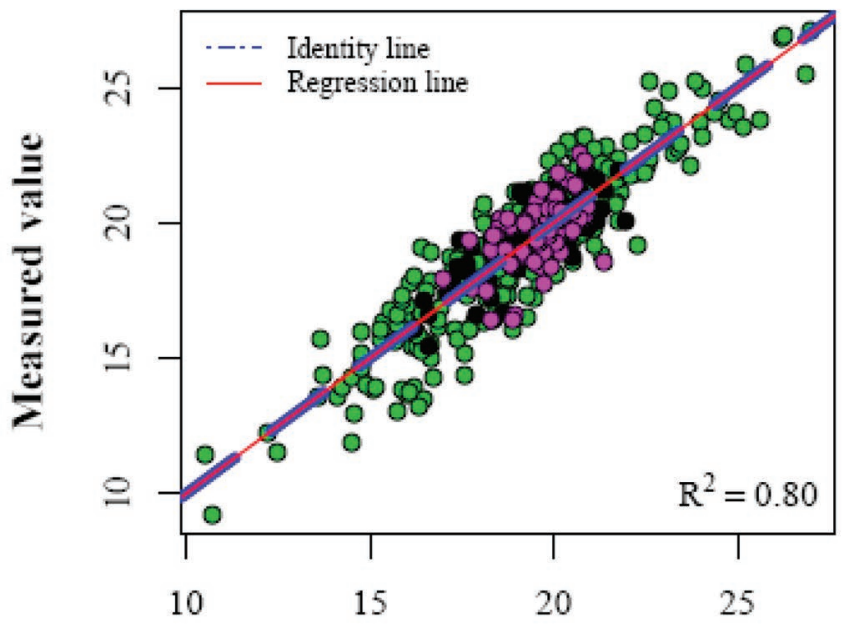

Predicted value

Figure 1. Scatter plots of reference (y-axis) versus predicted (x-axis) values for the best-predicted cheese-making traits using a partial least squares model built on all milk samples. (a) Fresh curd yield (CY $\mathrm{CPRSH}_{\mathrm{F}}$; \%); (b) curd yield in DM (CY $\mathrm{DM}_{\text {; }} \%$ ); (c) curd firmness after rennet coagulation time in pressed cooked cheese conditions of rennet coagulation [apcc; firmness index (FI)]; (d) curd firmness after rennet coagulation time in soft cheese conditions of rennet coagulation $\left(\mathrm{a}_{\mathrm{SC}} ; \mathrm{FI}\right)$. FI = volts $\times 10$. Green $=$ individual milk samples; black $=$ herd milk samples; pink = dairy vat milk samples; solid red line = regression line; dashed blue line $=$ first bisector. 
The implementation of an equation developed on milk samples with high variability on a population of milk samples with low variability (H-milk, V-milk) leads to a reduction in performance because the variability of the validation set is reduced compared with the performances of the calibration model. For this reason, the equations should be specific to each scale of production. Furthermore, in the specific case of V-milk or H-milk samples, we are not convinced that increasing the number of samples when most of the variability is already trapped can significantly increase the performance of the equations.

\section{CONCLUSIONS}

This study is the first to evaluate by MIR spectroscopy the CMP of Montbéliarde milks not only at the individual-scale milk production but also at the herd tank- and dairy vat-scale milk production to fulfil the expectations of cheese-makers. We confirm that the accuracy of the models depends on the number of samples and the variability of their characteristics, which were higher for I-milk samples than for H-milk samples and higher for H-milk samples than for V-milk samples. For most CMP traits, the prediction models developed either on the entire data set (this study) or on the individual data set (El Jabri et al., 2019) have shown similar accuracy, meaning that they could be used equally for genetic purposes. We already successfully used the prediction models developed on all samples of milks $(\mathrm{n}=420)$ to assess genetic variability of CMP within the population of Montbéliarde cows, confirm candidate causative variants on CMP, or reveal new genes co-associated with milk CMP and milk composition in this population (Sanchez et al., 2018a,b, 2019). The relationships between the fine physicochemical composition of the milks and their CMP will be studied at each production scale. Another objective of this project is to identify factors contributing to the CMP variation at different scales of the PDO and PGI milk production system (cow, herd, and dairy cooperative) by using MIR spectroscopy prediction methods when their accuracy is acceptable or, alternatively, reference analytical methods.

\section{ACKNOWLEDGMENTS}

This study was funded by the French Ministry of Agriculture, Agro-Food and Forest (Paris, France), the French Dairy Interbranch Organization (CNIEL, Paris, France), the Regional Union of Protected Designation cheeses of Franche-Comté (URFAC, Poligny, France), and the Regional Council of Bourgogne Franche-Comté
(Besançon, France) under the project FROM'MIR. The authors have not stated any conflicts of interest.

\section{REFERENCES}

Benedet, A., C. L. Manuelian, M. Penasa, M. Cassandro, F. Righi, M. Sternieri, P. Galimberti, A. V. Zambrini, and M. De Marchi. 2018. Factors associated with herd bulk milk composition and technological traits in the Italian dairy industry. J. Dairy Sci. 101:934-943. https://doi.org/10.3168/jds.2017-12717.

Bland, J. H., A. P. Bailey, A. S. Grandison, and C. C. Fagan. 2015a. Short communication: Estimation of the financial benefit of using Jersey milk at different inclusion rates for Cheddar cheese production using partial budgeting. J. Dairy Sci. 98:1661-1665. https:// doi.org/10.3168/jds.2014-8723.

Bland, J. H., A. S. Grandison, and C. C. Fagan. 2015b. Effect of blending Jersey and Holstein-Friesian milk on Cheddar cheese processing, composition, and quality. J. Dairy Sci. 98:1-8. https://doi .org $/ 10.3168 /$ jds.2014-8433.

Coppa, M., A. Ferlay, C. Leroux, M. Jestin, Y. Chilliard, B. Martin, and D. Andueza. 2010. Prediction of milk fatty acid composition by near infrared reflectance spectroscopy. Int. Dairy J. 20:182-189. https://doi.org/10.1016/j.idairyj.2009.11.003.

Corrieu, G., H. E. Spinnler, Y. Jomier, and D. Picque. 1988. Automated system to follow up and control the acidification activity of lactic acid starters. French Patent FR 2629612 October 1989.

Dal Zotto, R., M. De Marchi, A. Cecchinato, M. Penasa, M. Cassandro, P. Carnier, L. Gallo, and G. Bittante. 2008. Reproducibility and repeatability of measures of milk coagulation properties and predictive ability of mid-infrared reflectance spectroscopy. J. Dairy Sci. 91:4103-4112. https://doi.org/10.3168/jds.2007-0772.

De Marchi, M., R. Dal Zotto, M. Cassandro, and G. Bittante. 2007. Milk coagulation ability of five dairy cattle breeds. J. Dairy Sci. 90:3986-3992. https://doi.org/10.3168/jds.2006-627.

De Marchi, M., C. C. Fagan, C. P. O'Donnell, A. Cecchinato, R. Dal Zotto, M. Cassandro, M. Penasa, and G. Bittante. 2009. Prediction of coagulation properties, titratable acidity, and $\mathrm{pH}$ of bovine milk using mid-infrared spectroscopy. J. Dairy Sci. 92:423-432. https://doi.org/10.3168/jds.2008-1163.

De Marchi, M., M. Penasa, A. Zidi, and C. L. Manuelian. 2018. Invited review: Use of infrared technologies for the assessment of dairy products-Applications and perspectives. J. Dairy Sci. 101:1058910604. https://doi.org/10.3168/jds.2018-15202.

De Marchi, M., V. Toffanin, M. Cassandro, and M. Penasa. 2013. Prediction of coagulating and noncoagulating milk samples using mid-infrared spectroscopy. J. Dairy Sci. 96:4707-4715. https://doi .org/10.3168/jds.2012-6506.

De Marchi, M., V. Toffanin, M. Cassandro, and M. Penasa. 2014. Invited review: Mid-infrared spectroscopy as phenotyping tool for milk traits. J. Dairy Sci. 97:1171-1186. https://doi.org/10.3168/ jds.2013-6799.

El Jabri, M., M.-P. Sanchez, P. Trossat, C. Laithier, V. Wolf, P. Grosperrin, E. Beuvier, O. Rolet-Répécaud, S. Gavoye, Y. Gaüzère, O. Belysheva, E. Notz, D. Boichard, and A. Delacroix-Buchet. 2019. Comparison of Bayesian and partial least squares regression methods for mid-infrared prediction of cheese-making properties in Montbéliarde cows. J. Dairy Sci. 102:6943-6958. https://doi.org/ 10.3168/jds.2019-16320.

Ferrand-Calmels, M., I. Palhière, M. Brochard, O. Leray, J. M. Astruc, M. R. Aurel, S. Barbey, F. Bouvier, P. Brunschwig, H. Caillat, M. Douguet, F. Faucon-Lahalle, M. Gelé, G. Thomas, J. M. Trommenschlager, and H. Larroque. 2014. Prediction of fatty acid profiles in cow, ewe, and goat milk by mid-infrared spectrometry. J. Dairy Sci. 97:17-35. https://doi.org/10.3168/jds.2013-6648.

Frederiksen, P. D., K. K. Andersen, M. Hammersh øj, H. D. Poulsen, J. Sørensen, M. Bakman, K. B. Qvist, and L. B. Larsen. 2011. Composition and effect of blending of noncoagulating, poorly coagulating, and well-coagulating bovine milk from individual Dan- 
ish Holstein cows. J. Dairy Sci. 94:4787-4799. https://doi.org/10 $.3168 /$ jds.2011-4343.

Gottardo, P., M. De Marchi, M. Cassandro, and M. Penasa. 2015. Technical note: Improving the accuracy of mid-infrared prediction models by selecting the most informative wavelengths. J. Dairy Sci. 98:4168-4173. https://doi.org/10.3168/jds.2014-8752.

Grelet, C., J. A. Fernández Pierna, P. Dardenne, V. Baeten, and F. Dehareng. 2015. Standardization of milk mid-infrared spectra from a European dairy network. J. Dairy Sci. 98:2150-2160. https://doi .org/10.3168/jds.2014-8764.

Grubbs, F. E. 1969. Procedures for detecting outlying observations in samples. Technometrics 11:1-21. https://doi.org/10.1080/ 00401706.1969.10490657.

Hurtaud, C., H. Rulquin, and R. Verite. 1993. Effect of infused volatile fatty acids and caseinate on milk composition and coagulation in dairy cows. J. Dairy Sci. 76:3011-3020. https://doi.org/10.3168/ jds.S0022-0302(93)77640-7.

ISO (International Organization for Standardization). 2009. ISO 81962/IDF 128-2. Milk-Definition and evaluation of the overall accuracy of alternative methods of milk analysis. Part 2: Calibration and quality control in the dairy laboratory. ISO, Geneva, Switzerland.

Lin, Y., J. A. O'Mahony, A. L. Kelly, and T. P. Guinee. 2017. Seasonal variation in the composition and processing characteristics of herd milk with varying proportions of milk from spring-calving and autumn-calving cows. J. Dairy Res. 84:444-452. https://doi .org/10.1017/S0022029917000516

Malacarne, M., A. Summer, E. Fossa, P. Formaggioni, P. Franceschi, M. Pecorari, and P. Mariani. 2006. Composition, coagulation properties and Parmigiano-Reggiano cheese yield of Italian Brown and Italian Friesian herd milks. J. Dairy Res. 73:171-177. https://doi .org/10.1017/S0022029905001688.

Malacarne, M., A. Summer, P. Franceschi, P. Formaggioni, M. Pecorari, G. Panari, P. Vecchia, S. Sandri, E. Fossa, C. Scotti, and P. Mariani. 2013. Effects of storage conditions on physico-chemical characteristics, salt equilibria, processing properties and microbial development of raw milk. Int. Dairy J. 29:36-41. https://doi.org/ 10.1016/j.idairyj.2012.10.005.

Manuelian, C. L., M. Penasa, G. Giangolini, C. Boselli, S. Currò, and M. De Marchi. 2019. Short communication: Fourier-transform mid-infrared spectroscopy to predict coagulation and acidity traits of sheep bulk milk. J. Dairy Sci. 102:1927-1932. https://doi.org/ $10.3168 /$ jds.2018-15259.

NF V04-294 standard. 1996. Milk-Liquid lactoserum-Determination of solids content.

O'Brien, B., W. J. Meaney, D. McDonagh, and A. Kelly. 2001. Influence of somatic cell count and storage interval on composition and processing characteristics of milk from cows in late lactation. Aust. J. Dairy Technol. 56:213-218.

O'Connell, A., A. Kelly, J. Tobin, P. L. Ruegg, and D. Gleeson. 2017. The effect of storage conditions on the composition and functional properties of blended bulk tank milk. J. Dairy Sci. 100:991-1003. https://doi.org/10.3168/jds.2016-11314.

Penasa, M., V. Toffanin, N. Cologna, M. Cassandro, and M. De Marchi. 2016. Effects of dairy factory, milk casein content and titratable acidity on coagulation properties in Trentingrana dairy industry. J. Dairy Res. 83:242-248. https://doi.org/10.1017/ S0022029916000212.

Sanchez, M. P., M. El Jabri, S. Minéry, V. Wolf, E. Beuvier, C. Laithier, A. Delacroix-Buchet, M. Brochard, and D. Boichard. 2018a. Genetic parameters for cheese-making properties and milk composition predicted from mid-infrared spectra in a large data set of Montbéliarde cows. J. Dairy Sci. 101:10048-10061. https://doi .org/10.3168/jds.2018-14878.

Sanchez, M.-P., Y. Ramayo-Caldas, V. Wolf, C. Laithier, M. El Jabri, A. Michenet, M. Boussaha, S. Taussat, S. Fritz, A. DelacroixBuchet, M. Brochard, and D. Boichard. 2019. Sequence-based GWAS, network and pathway analyses reveal genes co-associated with milk cheese-making properties and milk composition in Montbéliarde cows. Genet. Sel. Evol. 51:34. https://doi.org/10.1186/ s12711-019-0473-7.

Sanchez, M. P., V. Wolf, M. El Jabri, E. Beuvier, O. Rolet-Répécaud, Y. Gaüzère, S. Minéry, M. Brochard, A. Michenet, S. Taussat, A Barbat-Leterrier, A. Delacroix-Buchet, C. Laithier, S. Fritz, and D. Boichard. 2018b. Short communication: Confirmation of candidate causative variants on milk composition and cheesemaking properties in Montbéliarde cows. J. Dairy Sci. 101:10076-10081. https://doi.org/10.3168/jds.2018-14986.

Summer, A., P. Franceschi, P. Formaggioni, and M. Malacarne. 2014. Characteristics of raw milk produced by free-stall or tie-stall cattle herds in the Parmigiano-Reggiano cheese production area. Dairy Sci. Technol. 94:581-590. https://doi.org/10.1007/s13594-014 -0181-6.

Summer, A., P. Franceschi, P. Formaggioni, and M. Malacarne. 2015. Influence of milk somatic cell content on Parmigiano-Reggiano cheese yield. J. Dairy Res. 82:222-227. https://doi.org/10.1017/ S0022029915000102.

Summer, A., M. Pecorari, E. Fossa, N. Macciotta, and P. Vecchia. 2006. Influence of storage conditions on milk rennet-coagulation properties in Parmigiano-Reggiano cheesemaking. Vet. Res. Commun. 30(Suppl. 1):387-389. https://doi.org/10.1007/s11259-006 $-0088-7$.

Toffanin, V., M. De Marchi, M. Penasa, P. Denis, and M. Cassandro. 2012. Characterization of milk coagulation ability in bulk milk samples. Acta Agric. Slov. 100:93-98.

Viscarra Rossel, R. A., R. N. McGlynn, and A. B. McBratney. 2006. Determining the composition of mineral-organic mixes using UVvis-NIR diffuse reflectance spectroscopy. Geoderma 137:70-82. https://doi.org/10.1016/j.geoderma.2006.07.004.

Visentin, G., A. McDermott, S. McParland, D. P. P. Berry, O. A. A. Kenny, A. Brodkorb, M. A. A. Fenelon, and M. De Marchi. 2015. Prediction of bovine milk technological traits from mid-infrared spectroscopy analysis in dairy cows. J. Dairy Sci. 98:6620-6629. https://doi.org/10.3168/jds.2015-9323.

\section{ORCIDS}

M. El Jabri ๑ https://orcid.org/0000-0002-8563-2407

E. Beuvier ๑ https://orcid.org/0000-0001-7065-0090

A. Delacroix-Buchet (ํ) https://orcid.org/0000-0002-8065-560X 